\title{
Antifungal Potential of Transition Metal Hexacyanoferrates against Fungal Diseases of Mushroom
}

\author{
Charu Arora Chugh, Dipti Bharti \\ Department of Chemistry, Lovely Professional University, Jalandhar, India \\ Email: charuarora77@gmail.com
}

Received July 9, 2012; revised August 12, 2012; accepted September 5, 2012

\begin{abstract}
Ferrocyanides of $\mathrm{Co}(\mathrm{II}), \mathrm{Ni}(\mathrm{II}), \mathrm{Cu}(\mathrm{II}), \mathrm{Zn}(\mathrm{II})$ and $\mathrm{Cd}(\mathrm{II})$ were synthesized and characterized by IR spectra, magnetic susceptibility, thermal gravimetric analysis, elemental analysis and $\mathrm{X}$ ray diffraction studies. Antimicrobial potential of these complexes have been evaluated. Antifungal screening of these complexes has been carried out against Mycogone perniciosa and Verticillium fungicola causing wet and dry bubble diseases of button mushroom respectively. Nickel ferrocyanide has been found to be most effective against Mycogone perniciosa with $60 \%$ inhibitory effect while cadmium ferrocyanide has exhibited significant potential of $85 \%$ against Verticillium fungicola.
\end{abstract}

Keywords: Verticilium Fungicola; Mycogone Perniciosa; Biocidal Potential; Transition Metal Hexacyanoferrates

\section{Introduction}

Many of the transition metal ions in the living systems work as enzymes or carriers in macrocyclic ligand field environment. Therefore meaningful research in this direction might generate simple models for biologically occurring metallo enzymes and thus will help in developing our understanding of biological systems. These ligands are also of theoretical interest as they are capable of furnishing an environment of controlled geometry and ligand field strength [1-5]. Synthesis of a number of polydentatemacrocyclic ligands and their metal complexes has been reported in literature [6].Transition metals have an important place within medicinal biochemistry. Review of literature has revealed significant progress in utilization of transition metal complexes as drugs to treat several human diseases like carcinomas, lymphomas, infection control etc. These complexes act as therapeutic and antimicrobial agents [7-13]. Transition metals exhibit different oxidation states and can interact with a number of negatively charged molecules. This activity of transition metals has started the development of metal based drugs with promising pharmacological application and may offer unique therapeutic opportunities. To provide an update on recent advances in the medicinal use of transition metals, a Medline search has been carried out to identify the recent relevant literature $[14,15]$.

These complexes may possess antimicrobial activity against pathogenic fungi being used as a test organism in the present study. It is well established that metal ferrocyanides acts as adsorbent $[16,17]$, ion-exchangers [18, 19] and photosensitizers [20].Transition metals such as zinc, copper, cobalt, manganese, iron have been reported to be essential for crops. They remain in soil in small quantity and known as micronutrient. If the deficiency of these elements is detected in soil these are recommended to be added to soil with fertilizer or in form of top dressing. Thus these metals act as micronutrient in trace quantity and hence application of metal complexes in combination with other ecofriendly chemicals/botanicals may be evaluated for antimicrobial potential.

Mushrooms can provide more than just taste and texture for our meals-they actually have a surprisingly high nutritional value also. White button mushrooms have a surprising amount of nutrients including niacin, riboflavin, folate, phosphorus, iron, panthothenic acid, zinc, potassium, copper, magnesium, vitamin B6, selenium and thiamin. In addition, white button mushroom extract has been found to reduce the size of some cancer tumors and slow down the production of some cancer cells. It is most prominently linked to reducing the risk of breast and prostate cancer. The yield of the crop is severely affected by fungal pathogens Mycogone perniciosa and Verticillium fungicola causing wet and dry bubble diseases of button mushroom respectively. During the last decade V. fungicola has become less sensitive to the only approved chemical (prochloraz) that is still effective to treat infection. Moreover, it is expected that prochloraz will be banned from commercial mushroom growing. Therefore, alternative strategies to control the disease are urgently needed. Wet bubble caused by M. perniciosa is a disease that often occurs on mushroom farms. It can be of very 
severe (when there are practically no healthy mushrooms left on the beds), and not that much (unitary diseased mushrooms) depending on the time when the infection occurred; and the degree of infection.

Keeping in view the above facts present study has been undertaken to synthesize, characterize and evaluate antifungal activity of complexes of $\mathrm{Mn}(\mathrm{II}), \mathrm{Co}(\mathrm{II}), \mathrm{Ni}(\mathrm{II})$, $\mathrm{Cu}(\mathrm{II}), \mathrm{Zn}(\mathrm{II})$ and $\mathrm{Cd}$ (II) against Mycogone perniciosa and Verticillium fungicola causing wet and dry bubble diseases of mushroom respectively.

\section{Materials and Methods}

\subsection{Synthesis of Metal Ferrocyanides}

Six transition metal ferrocyanides namely manganese ferrocyanide, cobalt ferrocyanide, nickel ferrocyanide, copper ferrocyanide, zinc ferrocyanide and cadmium ferrocyanide were synthesized following Kourim's method [21]. A solution of potassium ferrocyanide $(167 \mathrm{ml}, 0.1$ M) was added to solution of desired metal salt $(500 \mathrm{ml}$, $0.1 \mathrm{M})$ with constant stirring at room temperature. A slight excess of metal salt solution markedly improves the coagulation of the precipitate. The reaction mixture was heated on a water bath at $80^{\circ} \mathrm{C}$ for $3-4 \mathrm{hrs}$, and allowed to stand at ambient temperature for $24 \mathrm{hrs}$. The precipitate was filtered under vacuum and washed thoroughly with double distilled water. It was dried in an oven at $60^{\circ} \mathrm{C}$. The dried product was ground and sieved to 100 mesh size. Coloured powders thus obtained were stable on exposure of air and moisture. All the synthesized complexes were found to be insoluble in water. These were characterized on the basis of elemental analysis, carried out on Carlo Erba $1108 \mathrm{CHN}$ analyzer and Atomic Absorption Spectrophotometer (Perkin Elmer 3100), IR spectra (recorded on Bio-Rad FTIR spectrophotometer), magnetic susceptibility measurement (recorded on VSM-155), molar conductivity measurement and $\mathrm{X}$ ray diffraction studies. The data has been reported in Tables 1-9.

\subsection{Collection of Fungal Cultures}

Two fungal pathogens namely Mycogone perniciosa and Verticillium fungicola causing wet and dry bubble diseases of button mushroom respectively, have been collected from Department of Plant Pathology, College of Agriculture, G.B. Pant University of Agriculture and Technology, Pantnagar. Both these fungal pathogens were grown on potato dextrose agar (PDA) medium and incubated at $20^{\circ} \mathrm{C}$ and $28^{\circ} \mathrm{C}$ respectively.

\subsection{Screening of Metal Complexes for Fungicidal Activity}

Paper disc method, based on diffusion capacity of test chemical(s) through agar medium has been used for pre- liminary screening of antifungal activity of metal complexes [22]. Fungal plug were placed at the center of assay plate containing sterilized PDA and allowed to grow. After circular growth of about $2-3 \mathrm{~cm}$ diameter four sterilized paper disc (two loaded with $20 \mu$ aqueous sus-

Table 1. Elemental analysis data of metal ferrocyanides.

\begin{tabular}{lccccc}
\hline \multirow{2}{*}{$\begin{array}{l}\text { Metal } \\
\text { Com- } \\
\text { plexes }\end{array}$} & \multicolumn{5}{c}{ \% found (calculated) } \\
\cline { 2 - 6 } & Metal & $\mathrm{Fe}$ & $\mathrm{N}$ & $\mathrm{C}$ & $\mathrm{H}$ \\
\hline $\mathrm{MnFC}$ & 28.56 & 14.66 & 22.59 & 20.67 & 1.69 \\
& $(29.23)$ & $(14.86)$ & $(22.36)$ & $(19.17)$ & $(1.61)$ \\
$\mathrm{CoFC}$ & 32.12 & 15.30 & 21.16 & 19.65 & 1.11 \\
& $(32.22)$ & $(15.27)$ & $(22.97)$ & $(19.70)$ & $(1.10)$ \\
$\mathrm{NiFC}$ & 27.85 & 13.00 & 18.79 & 16.51 & 2.22 \\
& $(27.93)$ & $(13.28)$ & $(19.19)$ & $(17.14)$ & $(2.30)$ \\
$\mathrm{CuFC}$ & 27.10 & 12.10 & 18.12 & 14.75 & 3.13 \\
& $(27.32)$ & $(12.01)$ & $(18.07)$ & $(15.49)$ & $(3.03)$ \\
$\mathrm{ZnFC}$ & 32.84 & 14.10 & 20.40 & 17.74 & 1.51 \\
& $(32.95)$ & $(14.08)$ & $(21.18)$ & $(18.16)$ & $(1.45)$ \\
$\mathrm{CdFC}$ & 50.12 & 12.58 & 20.38 & 17.71 & 0.26 \\
& $(51.47)$ & $(12.79)$ & $(19.24)$ & $(16.50)$ & $(0.00)$ \\
\hline
\end{tabular}

Table 2. Infrared spectral peak assignment of metal ferrocyanide complexes.

\begin{tabular}{lccccc}
\hline & \multicolumn{5}{c}{ Adsorption frequencies $\left(\mathrm{cm}^{-1}\right)$} \\
\cline { 2 - 6 } Complexes & $v_{\mathrm{HOH}}$ & $v_{\mathrm{C} \equiv \mathrm{N}}$ & $\begin{array}{c}\mathrm{HOH} \\
\text { bending }\end{array}$ & $v_{\mathrm{Fe}-\mathrm{C}}$ & $v_{\text {Metal-N }}$ \\
\hline $\mathrm{Mn}_{2}\left[\mathrm{Fe}(\mathrm{CN})_{6}\right] \cdot 3 \mathrm{H}_{2} \mathrm{O}$ & 3701 & 2070 & 1631 & 592 & 451 \\
$\mathrm{Co}_{2}\left[\mathrm{Fe}(\mathrm{CN})_{6}\right] \cdot 2 \mathrm{H}_{2} \mathrm{O}$ & 3724 & 2083 & 1609 & 592 & 465 \\
$\mathrm{Ni}_{2}\left[\mathrm{Fe}(\mathrm{CN})_{6}\right] \cdot 5 \mathrm{H}_{2} \mathrm{O}$ & 3697 & 2091 & 1611 & 592 & 463 \\
$\mathrm{Cu}_{2}\left[\mathrm{Fe}(\mathrm{CN})_{6}\right] \cdot 7 \mathrm{H}_{2} \mathrm{O}$ & 3845 & 2090 & 1621 & 592 & 503 \\
$\mathrm{Zn}_{2}\left[\mathrm{Fe}(\mathrm{CN})_{6}\right] \cdot 3 \mathrm{H}_{2} \mathrm{O}$ & 3685 & 2080 & 1600 & 603 & 496 \\
$\mathrm{Cd}_{2}\left[\mathrm{Fe}(\mathrm{CN})_{6}\right]$ & 3724 & 2071 & 1623 & 590 & 508 \\
\hline
\end{tabular}

Table 3. Magnetic moments and molar conductivity of metal ferrocyanide complexes.

\begin{tabular}{cccc}
\hline Metal hexacyanoferrate (II) & $\mu_{\text {calc }}($ B.M. $)$ & $\mu_{\text {eff }}($ B.M. $)$ & $\begin{array}{c}\text { Molar conductance } \\
(\mu \mathrm{S})\end{array}$ \\
\hline $\mathrm{Mn}_{2}\left[\mathrm{Fe}(\mathrm{CN})_{6}\right] \cdot 3 \mathrm{H}_{2} \mathrm{O}$ & 5.92 & 6.21 & 24.2 \\
$\mathrm{Co}_{2}\left[\mathrm{Fe}(\mathrm{CN})_{6}\right] \cdot 2 \mathrm{H}_{2} \mathrm{O}$ & 3.87 & 4.36 & 9.81 \\
$\mathrm{Ni}_{2}\left[\mathrm{Fe}(\mathrm{CN})_{6}\right] \cdot 5 \mathrm{H}_{2} \mathrm{O}$ & 2.83 & 2.99 & 6.61 \\
$\mathrm{Cu}_{2}\left[\mathrm{Fe}(\mathrm{CN})_{6}\right] \cdot 7 \mathrm{H}_{2} \mathrm{O}$ & 1.73 & 2.45 & 6.72 \\
$\mathrm{Zn}_{2}\left[\mathrm{Fe}(\mathrm{CN})_{6}\right] \cdot 3 \mathrm{H}_{2} \mathrm{O}$ & 0.00 & 0.81 & 2.70 \\
$\mathrm{Cd}_{2}\left[\mathrm{Fe}(\mathrm{CN})_{6}\right]$ & 0.00 & 0.90 & 7.44 \\
\hline
\end{tabular}

Table 4. Major X-ray absorption peaks in the XRD spectra of manganese ferrocyanide.

\begin{tabular}{cccc}
\hline $2 \theta$ & $\begin{array}{c}\text { d-Spacing }(\AA) \\
\text { observed }\end{array}$ & $\begin{array}{c}\text { Relative intensity } \\
(\%)\end{array}$ & $\begin{array}{c}\text { d-Spacing }[\AA] \\
\text { reported in PCPDF } \\
\text { database }\end{array}$ \\
\hline 17.6155 & 5.0348 & 56.48 & 5.8087 \\
24.9795 & 3.56478 & 100.00 & 3.5570 \\
29.6726 & 3.0117 & 7.07 & 3.0334 \\
39.1584 & 2.3005 & 6.69 & 2.3081 \\
40.0277 & 2.2525 & 9.91 & 2.5152 \\
43.4091 & 2.0846 & 5.28 & 2.9043 \\
\hline
\end{tabular}


Table 5. Major X-ray absorption peaks in the XRD spectra of cobalt ferrocyanide.

\begin{tabular}{cccc}
\hline $2 \theta$ & $\begin{array}{c}\text { d-Spacing }(\AA) \\
\text { observed }\end{array}$ & $\begin{array}{c}\text { Relative Intencity } \\
(\%)\end{array}$ & $\begin{array}{c}\text { d-Spacing }[\AA] \\
\text { reported in PCPDF } \\
\text { database }\end{array}$ \\
\hline 17.7134 & 5.0072 & 60.23 & 5.0300 \\
25.0657 & 3.5527 & 100.00 & 3.5600 \\
35.8547 & 2.5045 & 64.74 & 2.5300 \\
43.7255 & 2.0702 & 8.97 & 2.0800 \\
44.9538 & 2.0165 & 13.02 & 2.2800 \\
\hline
\end{tabular}

Table 6. Major X-ray absorption peaks in the XRD spectra of nickel ferrocyanide.

\begin{tabular}{|c|c|c|c|}
\hline $2 \theta$ & $\begin{array}{c}\text { d-Spacing }(\AA) \\
\text { observed }\end{array}$ & $\begin{array}{l}\text { Relative intensity } \\
(\%)\end{array}$ & $\begin{array}{c}\text { d-Spacing }[\AA] \\
\text { reported in PCPDF } \\
\text { database }\end{array}$ \\
\hline 17.7146 & 5.0069 & 60.93 & 5.0500 \\
\hline 25.0107 & 3.5604 & 100.00 & 3.5700 \\
\hline 35.7078 & 2.5145 & 53.31 & 2.5700 \\
\hline 40.1426 & 2.2463 & 10.26 & 2.2600 \\
\hline 44.0851 & 2.0542 & 15.62 & 2.0600 \\
\hline 51.3617 & 1.7789 & 10.64 & 1.7840 \\
\hline 54.7539 & 1.6765 & 4.39 & 1.6830 \\
\hline 57.9877 & 1.5891 & 11.22 & 1.5230 \\
\hline
\end{tabular}

Table 7. Major X-ray absorption peaks in the XRD spectra of copper ferrocyanide.

\begin{tabular}{cccc}
\hline $2 \theta$ & $\begin{array}{c}\text { d-Spacing }(\AA) \\
\text { observed }\end{array}$ & $\begin{array}{c}\text { Relative Intencity } \\
(\%)\end{array}$ & $\begin{array}{c}\text { d-Spacing[̊] } \\
\text { reported in PCPDF } \\
\text { database }\end{array}$ \\
\hline 25.1752 & 3.5375 & 79.69 & 3.5000 \\
29.7271 & 3.0054 & 7.41 & 3.0200 \\
36.0522 & 2.4913 & 36.50 & 2.5000 \\
40.3144 & 2.2372 & 14.79 & 2.2300 \\
44.3532 & 2.0424 & 12.34 & 2.0400 \\
\hline
\end{tabular}

Table 8. Major X-ray absorption peaks in the XRD spectra of Zinc ferrocyanide.

\begin{tabular}{cccc}
\hline $2 \theta$ & $\begin{array}{c}\text { d-Spacing }(\AA) \\
\text { observed }\end{array}$ & $\begin{array}{c}\text { Relative Intencity } \\
(\%)\end{array}$ & $\begin{array}{c}\text { d-Spacing }[\AA] \\
\text { reported in } \\
\text { PCPDF database }\end{array}$ \\
\hline 16.3677 & 5.4157 & 100.00 & 5.4000 \\
19.7227 & 4.5014 & 46.65 & 4.5100 \\
21.7924 & 4.0783 & 90.70 & 4.0800 \\
28.6684 & 3.1139 & 22.18 & 3.1100 \\
29.7535 & 3.0027 & 9.27 & 3.0000 \\
35.6073 & 2.5141 & 10.35 & 2.5400 \\
37.7830 & 2.3810 & 7.67 & 2.3700 \\
38.8405 & 2.3186 & 7.21 & 2.3200 \\
40.9696 & 2.2029 & 11.16 & 2.2000 \\
47.8545 & 1.9008 & 5.80 & 1.9500 \\
\hline
\end{tabular}

Table 9. Major X-ray absorption peaks in the XRD spectra of cadmium ferrocyanide.

\begin{tabular}{cccc}
\hline $2 \theta$ & $\begin{array}{c}\text { d-Spacing }(\AA) \\
\text { observed }\end{array}$ & $\begin{array}{c}\text { Relative intensity } \\
(\%)\end{array}$ & $\begin{array}{c}\text { d-Spacing }[\AA] \\
\text { reported in } \\
\text { PCPDF database }\end{array}$ \\
\hline 19.5467 & 4.5415 & 3.45 & 4.1100 \\
28.7088 & 3.1096 & 19.86 & 3.1600 \\
31.7556 & 2.8178 & 3.52 & 2.8300 \\
35.3196 & 2.5412 & 39.74 & 2.4900 \\
39.6586 & 2.2726 & 19.20 & 2.2300 \\
42.7467 & 2.1153 & 9.50 & 2.1100 \\
49.1373 & 1.8541 & 1.50 & 1.8180 \\
50.7909 & 1.7976 & 7.34 & 1.7470 \\
57.3244 & 1.6073 & 10.31 & 1.6670 \\
59.3363 & 1.5575 & 2.77 & 1.5760 \\
61.4229 & 1.5095 & 1.43 & 1.5350 \\
66.3195 & 1.4094 & 2.20 & 1.4740 \\
\hline
\end{tabular}

pension of metal ferrocyanides and two with sameamount of distilled water) were placed at equal distance from center in order to see the effect of metal ferrocyanides on the growth of fungal pathogen. Inhibition zones were measured after $36 \mathrm{hrs}$ of incubation. Dumb bell shaped growth of fungus was observed in case of metal complex possesing growth inhibitory component(s).

Food poisoning technique was used to find percent inhibition. For this purpose $0.375 \%(\mathrm{w} / \mathrm{v})$ metal complex was spread to each petri-dish containing the sterilized media, while in control treatment equal amount of pure solvent was added. The fungal plug was placed at the centre of petri-dish. Growth of fungus was recorded after $72 \mathrm{hrs}$ of incubation. The percent inhibition was calculated using the formula of Vincent [23].

Percent Inhibition $=(\mathrm{C}-\mathrm{T}) / \mathrm{C} \times 100$

Where $\mathrm{C}$ is the growth in control in $\mathrm{mm}$ and $\mathrm{T}$ is growth in treatment in $\mathrm{mm}$.

All the experiments were carried out in triplicate in randomized block design and average value was used for interpretation of results (Tables 5-9).

\subsubsection{Correlation Coefficient (r)}

The correlation coefficient $(r)$ was calculated using the following equation,

$$
r=\frac{n \sum x y-\sum x \sum y}{\sqrt{\left\{\left[n \sum x^{2}-\left(\sum x\right)^{2}\right]\left[n \sum y^{2}-\left(\sum y\right)^{2}\right]\right\}}}
$$

Here $n$ is the number of data points.

1) $r=+1$, perfect positive correlation, increase in one variable is accompanied by the increase in the other.

2) $r=-1$, perfect negative correlation, decrease in one variable is accompanied by the decrease in the other.

\subsubsection{Coefficient of Determination (“ $r$ ")}

Although correlation coefficient is a good measure of the 
strength of the association, but it has got no literal interpretation. The squared values of $r, r^{2}$ called coefficient of determination, however have a very clear meaning. It gives the measure of the proportion of variation in one variable associated with variations in the other. For example, if the value of $r=0.8$, then $r^{2}=0.64$. It means that $64 \%$ variations in the value of inhibition zones are associated with variation in metal complex and the remaining $36 \%$ can be attributed to some other unknown factors. The value of $r^{2}$ ranges from 0 to 1 .

\subsubsection{Significance Test}

The significance test ( $\mathrm{t}$ test) was performed and values of was calculated using the formula:

$$
t=r \frac{\sqrt{(n-2)}}{\sqrt{1-r^{2}}}
$$

Here, $n$ is number of observations.

The observed value of " $t$ " is compared with the critical value of $t$ obtained for $n-2$ degrees of freedom at $5 \%$ significance level from the $t$ distribution table [24].

\section{Results and Discussion}

\subsection{Characterization of Metal Ferrocyanides}

The molecular formula of synthesized metal complexes has been established on the basis of elemental analysis (Table 1) and thermal studies. Assignments of infra red peaks have been reported in Table 2 . A broad band in the range of $3400-3750 \mathrm{~cm}^{-1}$ has been observed due to interstitial water molecules and $\mathrm{OH}^{-}$groups while the characteristic $\mathrm{HOH}$ bending appears at $1600-1631 \mathrm{~cm}^{-1}$ in case of all the complexes synthesized. A sharp peak at $2080 \pm 10 \mathrm{~cm}^{-1}$ is characteristic of cyanide stretching. Sharp peaks at $691-590 \mathrm{~cm}^{-1}$ are characteristic of Fe-C stretching frequencies. $v_{\text {Metal-Nitrogen }}$ was observed at 451 $508 \mathrm{~cm}^{-1}$.

Values of observed and calculated magnetic moments have been reported in Table 3. From a structural stand point, the ferrocyanide ion can be considered to be a good example of strong field (low spin) octahedral complexes. In the presence of the strongly perturbing cyanide ligand the $3 \mathrm{~d}$ orbitals of ferrous ion will get splitted, causing a relatively large separation between $t_{2 \mathrm{~g}}$ and $\mathrm{e}_{\mathrm{g}}$ orbitals. In the ground state, therefore, the six electrons from $\mathrm{Fe}$ (II) ion will be placed in the low lying $t_{2 \mathrm{~g}}$ orbitals. The metal ions like $\mathrm{Zn}^{2+}, \mathrm{Co}^{2+}, \mathrm{Cu}^{2+}, \mathrm{Cr}^{3+}, \mathrm{Ni}^{2+}$, $\mathrm{Mn}^{2+}$ and $\mathrm{Cd}^{3+}$ will remain in the lattice.

All synthesized metal ferrocyanides are expected to be diamagnetic due to paired electrons. However, the outer cations may contribute to the observed magnetic moment, if any. The magnetic moment of $\mathrm{Mn}, \mathrm{Cu}, \mathrm{Co}$ and other ferrocyanides and found that zinc and cadmium ferro- cyanides are diamagnetic as expected. Observed magnetic moment values (Table 3) of these metal hexacyanoferrates were found to be in good agreement with calculated values. $\mu_{\mathrm{obs}}$ indicate presence of three unpaired electrons in cobalt ferrocyanide, which is in agreement with $\mathrm{d}^{7}$ configuration of $\mathrm{Co}^{2+}$, whereas reported value of magnetic moment for cobalt ferrocyanide is 4.6 BM. $\mu_{\text {obs }}$ values revealed that five, three, two and one unpaired electrons are present in $\mathrm{Mn}(\mathrm{II}), \mathrm{Co}(\mathrm{II}), \mathrm{Ni}(\mathrm{II})$, and $\mathrm{Cu}(\mathrm{II})$ hexacyanoferrates respectively, while zinc and cadmium hexacyanoferrates have zero magnetic moments.

Conductivity measurements (Table 3 ) in non aqueous solutions provide a method for testing the degree of ionization of the complexes. The value of molar conductance the soluble complexes in DMSO indicate these complexes to be poor electrolytes.

TG and DTA studies were carried out to confirm the presence of lattice water in metal hexacyanoferrates. Mass loss was found to be equivalent to three, two, five, seven, and three moles of water in case of $\mathrm{Mn}(\mathrm{II}), \mathrm{Co}(\mathrm{II}), \mathrm{Ni}(\mathrm{II})$, $\mathrm{Cu}(\mathrm{II})$, and $\mathrm{Zn}$ (II) hexacyanoferrate respectively. Cadmium ferrocyanide did not show any loss of water molecule. Molecular formula determined on the basis of elemental analysis, TG and DTA are as follows:

$\mathrm{Mn}_{2}\left[\mathrm{Fe}(\mathrm{CN})_{6}\right] \cdot 3 \mathrm{H}_{2} \mathrm{O}, \mathrm{Co}_{2}\left[\mathrm{Fe}(\mathrm{CN})_{6}\right] \cdot 2 \mathrm{H}_{2} \mathrm{O}$,

$\mathrm{Ni}_{2}\left[\mathrm{Fe}(\mathrm{CN})_{6}\right] \cdot 5 \mathrm{H}_{2} \mathrm{O}, \mathrm{Cu}_{2}\left[\mathrm{Fe}(\mathrm{CN})_{6}\right] \cdot 7 \mathrm{H}_{2} \mathrm{O}$,

$\mathrm{Zn}_{2}\left[\mathrm{Fe}(\mathrm{CN})_{6}\right] \cdot 3 \mathrm{H}_{2} \mathrm{O}$, and $\mathrm{Cd}_{2}\left[\mathrm{Fe}(\mathrm{CN})_{6}\right]$.

The synthesized metal complexes were characterized by $\mathrm{X}$ ray diffraction studies (Figure 1-6). $\mathrm{d}$ values of the observed peaks have been reported in Table (5-9) which are in good agreement with the published data for manganese, cobalt, nickel, copper, zinc and cadmium ferrocyanides in PC-PDF file numbers 46-0910, 23-0188, 14-0291, 01-0244, 24-0164, and 01-0433 respectively.

\subsection{Antifungal Potential}

Antifungal potential of metal complexes against $M$. perniciosa and $V$. fungicola has been reported in Table $\mathbf{1 0 .}$ Manganese, nickel, copper and zinc ferrocyanides have exhibited inhibition zones in the range of $2-4 \mathrm{~mm}$ with percent inhibition ranging 30\% - 60\% against $M$. pernici osa. Nickel ferrocyanide possesses maximum inhibitoryeffect against wet bubble causing pathogen $M$. perniciosa showing 60\% growth inhibition.

Manganese, cobalt, nickel, copper and cadmium ferrocyanide have exhibited inhibition zone ranging $2-18$ $\mathrm{mm}$ and percent inhibition in the range of $4 \%-85 \%$ against $V$. fungicola. Cadmium ferrocyanide has been found to be most effective against $V$. fungicola showing $85 \%$ growth inhibition. All the metal ferrocyanides except zinc ferrocyanide exhibit significant activity against $V$. fungicola.

The values of correlation coefficient (" $r$ ") and coeffi- 
nts

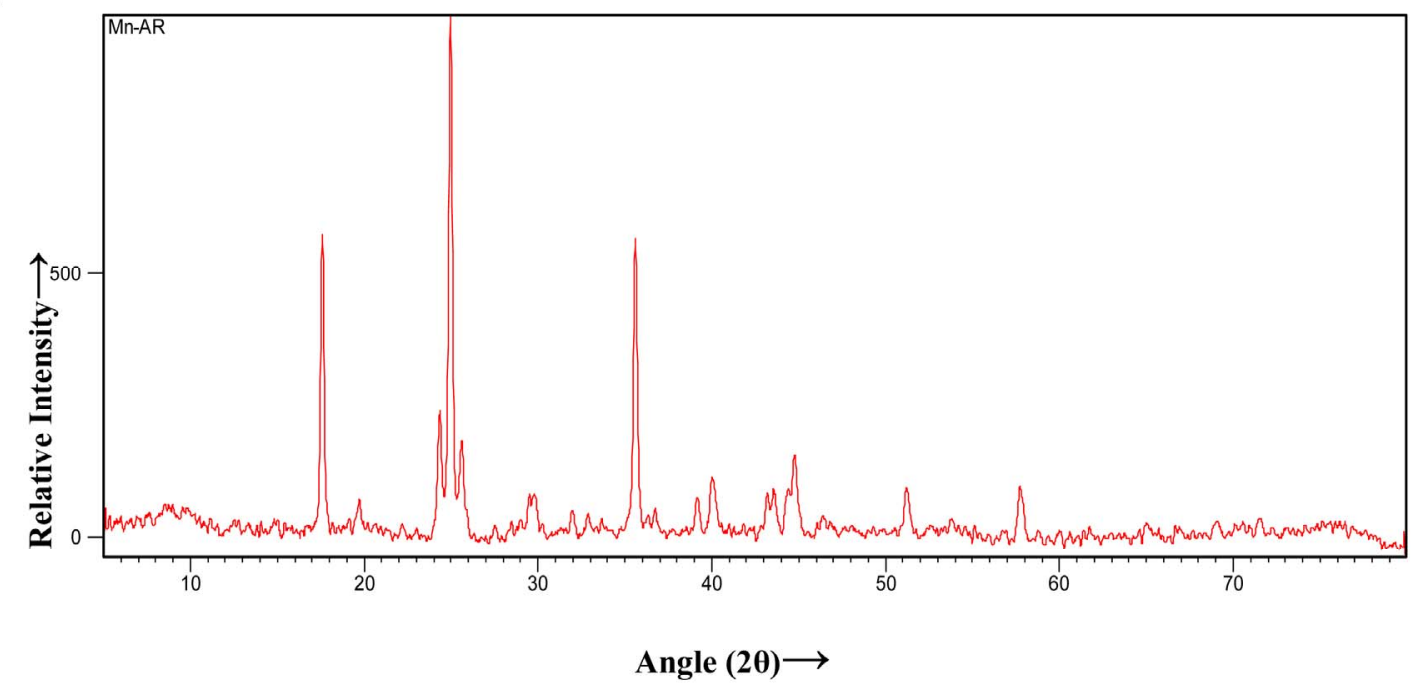

Figure 1. X-ray diffraction pattern for manganese ferrocyanide.

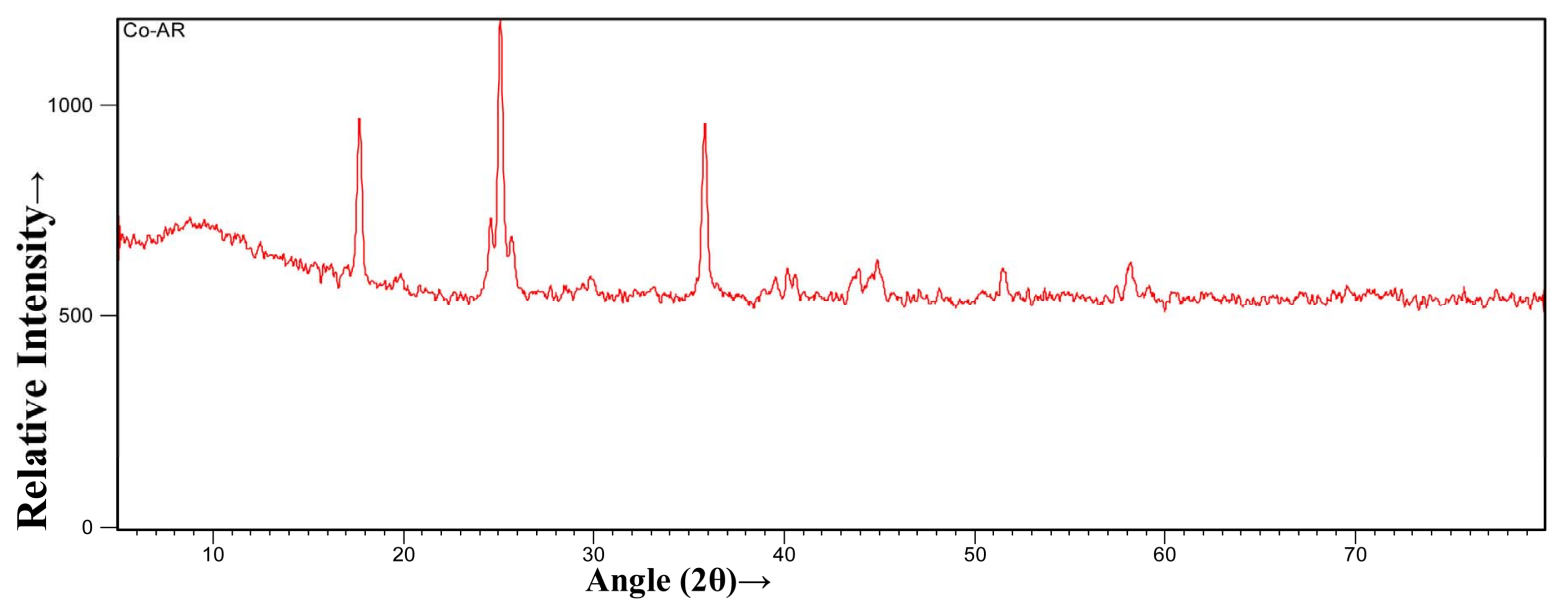

Figure 2. X-ray diffraction pattern for cobaltferrocyanide.

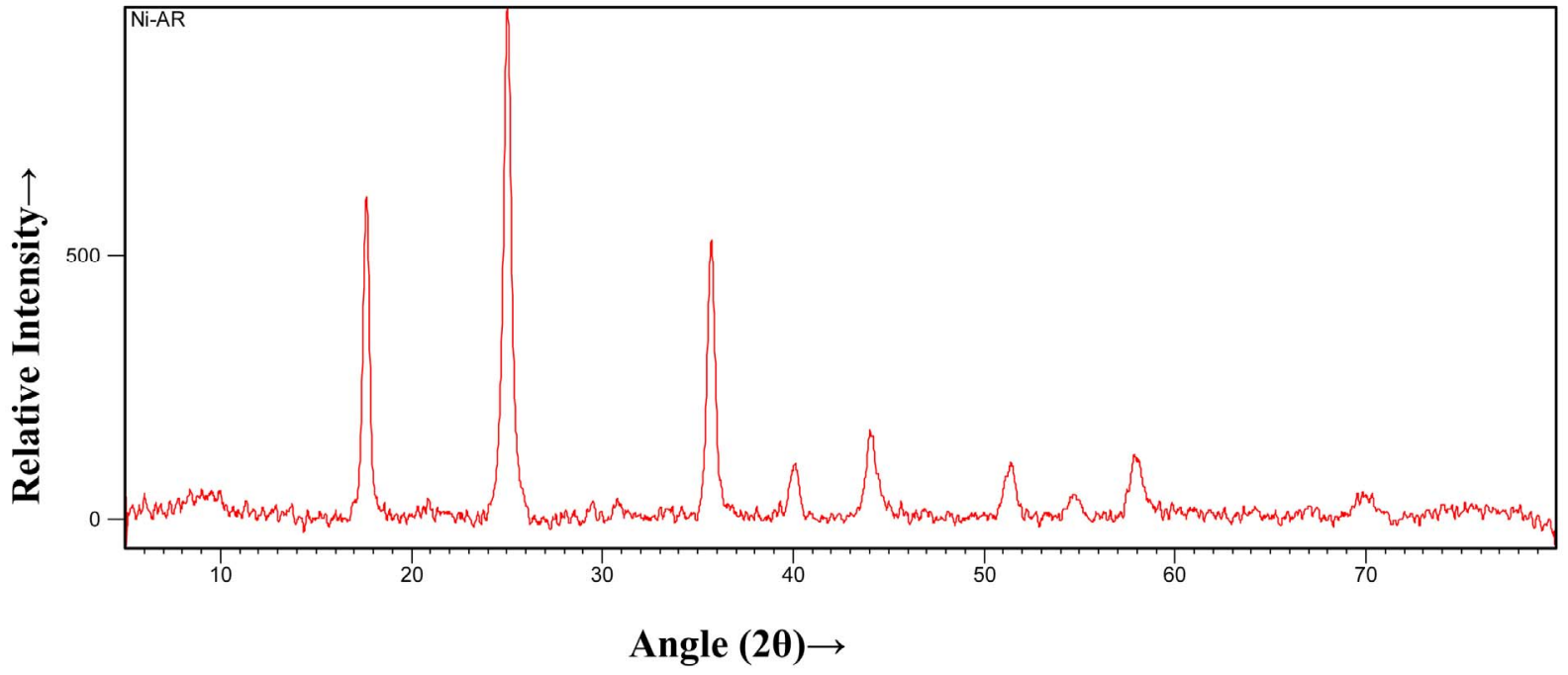

Figure 3. X-ray diffraction pattern for nickel ferrocyanide. 


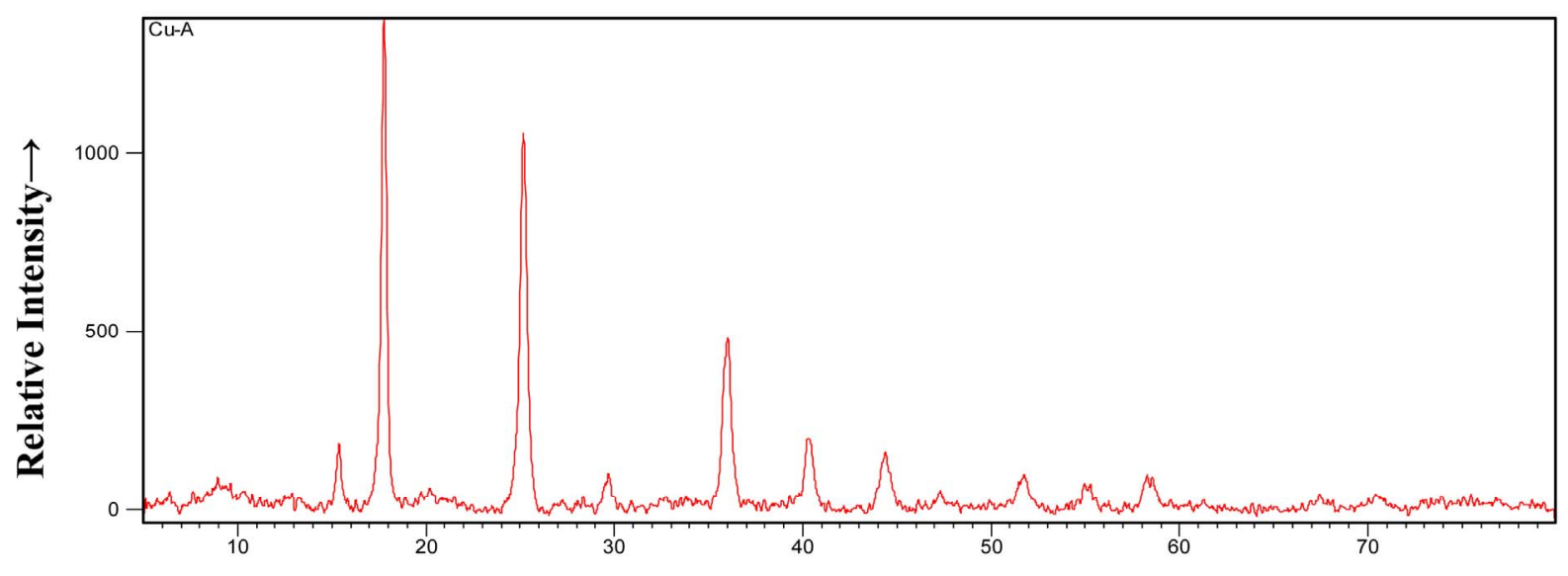

Angle (20) $\rightarrow$

Figure 4. X-ray diffraction pattern for copper ferrocyanide.

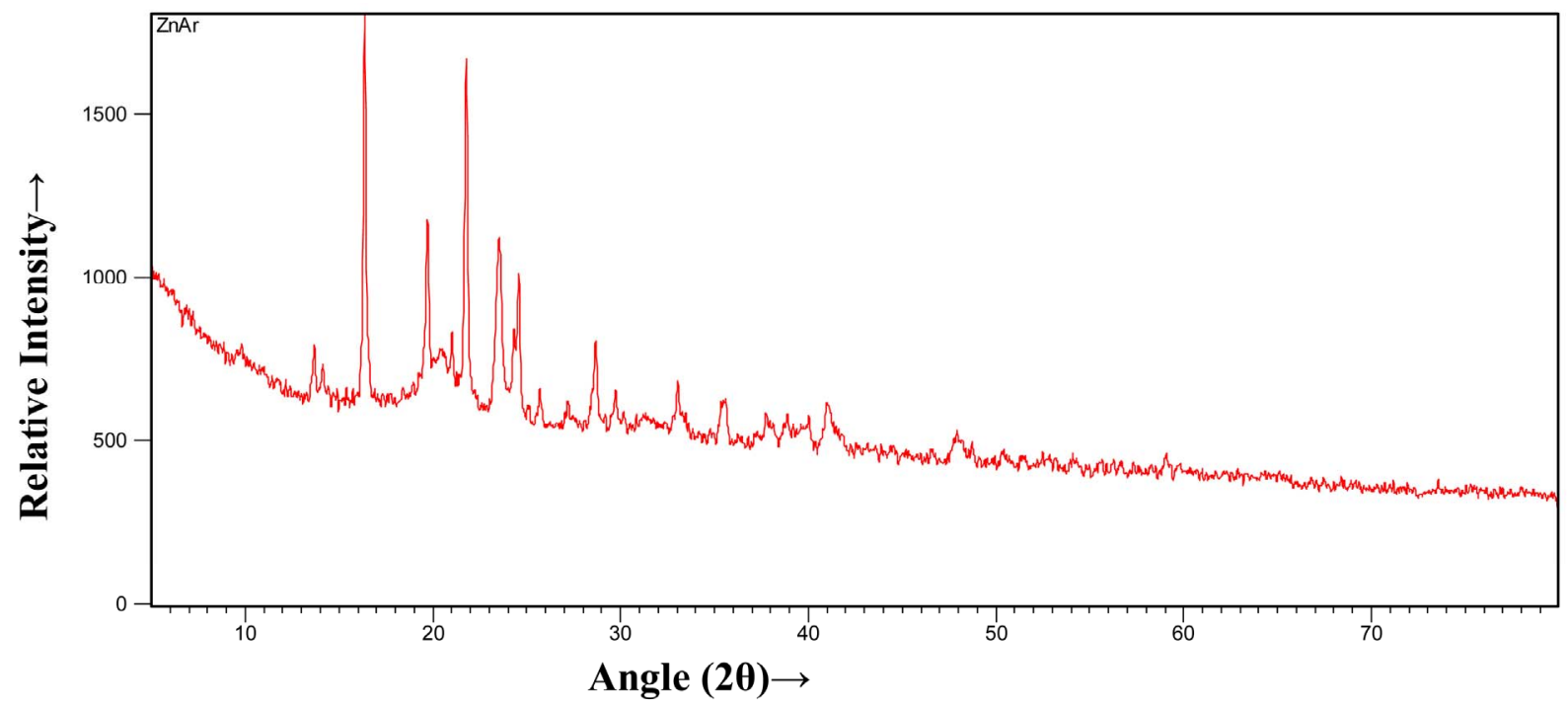

Figure 5. X-ray diffraction pattern for zinc ferrocyanide.

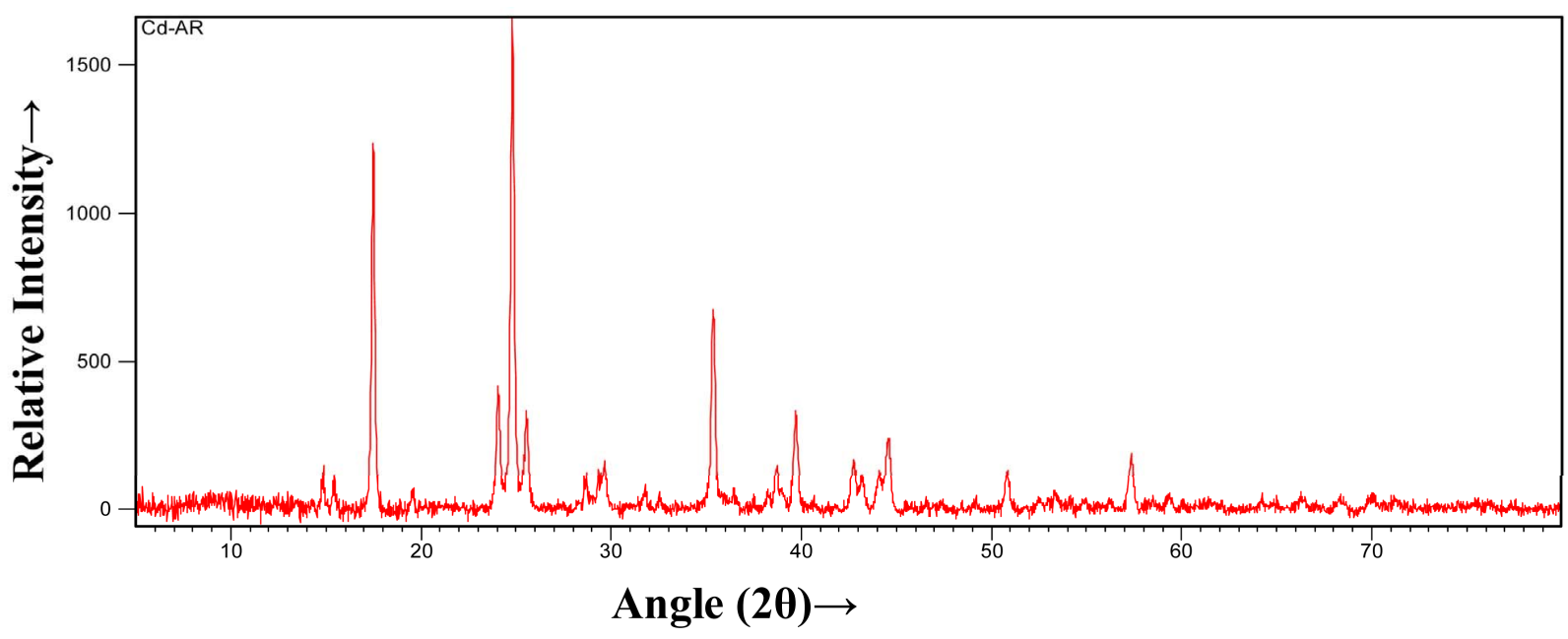

Figure 6. X-ray diffraction pattern for cadmium ferrocyanide. 
Table 10. Antifungal activity of transition metal ferrocyanides.

\begin{tabular}{lcccc}
\hline & $\begin{array}{c}\text { Fungal pathogen } \\
\text { Mycogoneperniciosa }\end{array}$ & $\begin{array}{c}\text { Fungal pathogen Verticel- } \\
\text { liumfungicola }\end{array}$ \\
\cline { 2 - 5 } Metal ferrocyanides & $\begin{array}{c}\text { Inhibition } \\
\text { zone (mm) }\end{array}$ & $\begin{array}{c}\text { Percent } \\
\text { inhibition }\end{array}$ & $\begin{array}{c}\text { Inhibition } \\
\text { zone }(\mathrm{mm})\end{array}$ & $\begin{array}{c}\text { Percent } \\
\text { inhibition }\end{array}$ \\
\hline $\mathrm{Mn}_{2}\left[\mathrm{Fe}(\mathrm{CN})_{6}\right] \cdot 3 \mathrm{H}_{2} \mathrm{O}$ & 2 & 30 & 7 & 32 \\
$\mathrm{Co}_{2}\left[\mathrm{Fe}(\mathrm{CN})_{6}\right] \cdot 2 \mathrm{H}_{2} \mathrm{O}$ & 0 & 00 & 8 & 38 \\
$\mathrm{Ni}_{2}\left[\mathrm{Fe}(\mathrm{CN})_{6}\right] \cdot 5 \mathrm{H}_{2} \mathrm{O}$ & 4 & 60 & 2 & 5 \\
$\mathrm{Cu}_{2}\left[\mathrm{Fe}(\mathrm{CN})_{6}\right] \cdot 7 \mathrm{H}_{2} \mathrm{O}$ & 3 & 50 & 15 & 75 \\
$\mathrm{Zn}_{2}\left[\mathrm{Fe}(\mathrm{CN})_{6}\right] \cdot 3 \mathrm{H}_{2} \mathrm{O}$ & 2 & 30 & - & - \\
$\mathrm{Cd}_{2}\left[\mathrm{Fe}(\mathrm{CN})_{6}\right]$ & 0 & 00 & 17 & 85 \\
\hline
\end{tabular}

The values of correlation coefficient (" $r$ ") and coefficient of determination (" $r$ ") are 0.997 and 0.994 respectively for observations related to the inhibitory effect against $M$. perniciosa. The value of " $r$ " suggests that $99.4 \%$ inhibition was caused by metal ferrocyanides and rest $0.6 \%$ may be attributed to other unknown and uncontrolled factors. The calculations related to the significance test ("t" test) revealed that the value of " $t$ " (25.73) is much higher than the critical value noted from " $t$ " distribution table for degree of freedom 4 at $5 \%$ significance level. This suggests that there are less than $5 \%$ chances of error in drawing the conclusions.

The calculated value of " $r$ ", " $r$ ", and " $t$ " (at $5 \%$ significance level), for the observations made in case of $V$. fungicola are $0.999,0.998$ and 51.50 respectively. The value of " $t$ " is much higher than the critical value which is indicative of less than $5 \%$ chances of occurrence of error, and that the null hypothesis may be safely rejected at $5 \%$ significance level.

There are few reports on synergistic effect of antimicrobial activity of metal ferrocyanide with botanicals [13]. These complexes have also been reported to adsorb biomolecules. Hence these may be proved to be potential solid support for plant based biocidal component(s). There may be the possibility of adsorption of active ingredient(s) at the surface of transitional metal ferrocyanides. Thus concentration, efficiency and shelf life of active chemical(s) may increase and lead to increased activity (biopotentiation). These studies will be helpful in development of new fungicidal formulations for management of dry and wet bubble diseases of button mushroom.

\section{Acknowledgements}

The author is thankful to University Grant Commission, New Delhi, India for providing financial support (F. No. 34-346\2008 SR) and Department of Plant Pathology,
College of Agriculture, Govind Ballabh Pant University of Agriculture and Technology, Pantnagar, Uttarakhand, India, for providing fungal cultures for present investigation.

\section{REFERENCES}

[1] B. A. El-Sayed, A. A. Shabana, M. M. Abo-Alyand and M. M. Sallam, "Electrical Transport as a Function of Temperature in Hexacyano Ferrate Complexes," Journal of materials Science: Materials in Electronics, Vol. 14, No. 1, 2003, pp. 27-31. doi:10.1023/A:1021523514752

[2] J. Fernandez-Bertran, E. Reguera, A. Dago and C. LopezHernandez, "Synthesis and Characterization of Two Complexes of Glycine with Lanthanum Hexacyanoferrate (III) and Hexacyanocobaltate (III)," Polyhedron, Vol. 15, No. 2, 1996, pp. 315-319. doi:10.1016/0277-5387(95)00179-V

[3] K.W. Hipps, U. Mazur and M. S. Pearce, "A Tunneling Spectroscopy Study of the Adsorption of Ferrocyanide from Water Solution by $\mathrm{Al}_{2} \mathrm{O}_{3}$," Chemical Physics Letters, Vol. 68, 1979, pp. 433-437.

[4] M. Shporer, G. Ron, A. Loewenstein and G. Navon, "Study of Some Cyano-Metal Complexes by Nuclear Magnetic Resonance. II. Kinetics of Electron Transfer between Ferri- and Ferrocyanide Ions," Inorganic Chemistry, Vol. 4, No. 3, 1965, pp. 361-364. doi:10.1021/ic50025a022

[5] R. Gobl, A. Zentko, J. Kovac, K. Csach, M. Zentkova and M. Miroslav, "Magnetic Properties of Uranium Ferrocyanides and Ferricyanides," Czechoslovak Journal of Physics, Vol.50, No.5, 2000, 671-676. doi:10.1023/A:1022818704161

[6] K. Itaya, I. Uchida and D. Vernon, "Electrochemistry of Polynuclear Transition Metal Cyanides: Prussian Blue and Its Analogues," Accounts of Chemical Research,Vol. 19, No. 6, 1986, pp. 162-168. doi:10.1021/ar00126a001

[7] B. A. Teicher, J. L. Jacobs, K. N. S. Cathcart, M. J. Abrams, J. F. Vollano and D. H. Picker, "Some Complexes of Cobalt(III) and Iron (III) Are Radiosensitizers of Hypoxic EMT6 Cells," Radiation Research, Vol. 109, No. 1, 1987, pp. 36-46.

[8] K. Sharmal, S. C. Joshi and R. V. Singh, "Fertility Inhibitor Heterobirnetallic Complexes of Platinum (II) and Palladium (II) Synthetic, Spectroscopic and Antimicrobial Aspects," Metal-Based Drugs, Vol. 7, No. 2, 2000, pp. 34 36.

[9] S. Rafique, M. Idrees, A. Nasim, H. Akbar and A. Athar, "Transition Metal Complexes as Potential Therapeutic Agents," Biotechnology and Molecular Biology Reviews, Vol. 5, No. 2, 2010, pp. 38-45.

[10] D. Bharti, C. Arora and G. Kaur, "Antifungal Screening of Some Transition Metal Ferrocyanides against Aspergillusniger and Candida albicans," Asian Journal of Chemistry, Vol. 24, No. 3, 2012, pp. 1064-1068.

[11] C. Arora and Vashali, "Synergistic Effect of Antimicrobial Constituents of Vitex negundo with Metal Ferrocynide," Progressive Agriculture: An International Journal, Vol. 9, 
No. 1, 2009, pp. 30-34.

[12] C. Arora and R. D. Kaushik, "Antifungal Activity of Some Transition Metal Ferrocyanides," Asian Journal of Chemistry, Vol. 15, No. 3-4, 2003, pp.1828-1830.

[13] D. Bharti, C. Arora and S. Gupta, "Synergistic Effect of Antifungal Activity of Medicinal Plants with Transition Metal Ferrocyanides against Rhizoctonia solani," Asian Journal of Chemistry, Vol. 24, No. 10, 2012, pp. 46504652.

[14] S. Ilhan, H. Temel, I. Yilmaz and A. Kilic, "Synthesis, Characterization and Redox Properties of Macrocyclic Schiff Base by Reaction of 2,6-Diaminopyridine and 1,3Bis(2-carboxyaldehyde phenoxy)propane and $\mathrm{Its}_{\mathrm{Cu}}{ }^{\mathrm{II}}, \mathrm{Ni}^{\mathrm{II}}$, $\mathrm{Pb}^{\mathrm{II}}$, Co ${ }^{\mathrm{III}}$ and $\mathrm{La}^{\mathrm{III}}$ complexes," Transition Metal Chemistry, Vol. 32, 2007, pp. 344-349. doi:10.1007/s11243-006-0174-2

[15] V.A. Palyulin, S. V. Emets, K. A. Potekhin, A. E. Lysov, Yu. G. Sumskaya and N. S. Zefirov, "Synthesis and Crystal and Molecular Structure of [1,3,5,7-Tetramethyl-3,7diazabicyclo[3.3.1]nonane]dichlorocopper(II)Monohydrate," Doklady Chemistry, Vol. 381, No. 4-6, 2001, pp. 369-371. doi:10.1023/A:1013333228403

[16] Kamaluddin, M. Nath and A. Sharma "Role of Metal Ferrocyanides in Chemical Evolution Adsorption of Ribose and 2'-Deoxyribose 5'-Nucleotides on Metal Ferrocyanides," Origins of Life and Evolution of the Biosphere, Vol. 24, No. 6, 1994, pp. 469-477.

[17] S. Viladkar, R. Agrawal and Kamaluddin, "Adsorption of Adenine, Adenosine and Adenosine Nucleotides on Nickel (II) Hexacyanoferrate(II)," Bulletin of the Chemical Society of Japan, Vol. 69, No. 1, 1996, pp. 95-100. doi:10.1246/bcsj.69.95

[18] W. U. Malik, S. K. Srivastava, U. M. Bhandari and S. Kumar, "Ion-Exchange Properties of Chromium Ferrocyanide," Journal of Inorganic and Nuclear Chemistry, Vol. 38, No. 2, 1976, pp. 342-343. doi:10.1016/0022-1902(76)80427-7

[19] J. Bastian and K. H. Lieser, "Ionenaustausch-gleichgewichte an Titanhexacyanoferrat (II)," Journal of Inorganic and Nuclear Chemistry, Vol. 29, No. 3, 1967, pp. 827-832. doi:10.1016/0022-1902(67)80340-3

[20] B. B. Tewari and Kamaluddin, "Photosensitized Oxidation of Diphenylamine Using Nickel Ferrocyanide And Its Relevance In Chemical Evolution, Proceedings of Ninth National Space Science Symposium (NSSS-96)," Osmania University, Hyderabad, 1996.

[21] V. Kourim, J. Rais and B. Millon, "Exchange Properties of Complex Cyanides-I (Ion-Exchange of Caesium on Ferrocyanides)," Journal of Inorganic and Nuclear Chemistry, Vol. 26, No. 6, 1964, pp. 1111-1115.

[22] C. Perez, M. Paul and P. Bazerque, "Antibiotic Assay by Agar Well Diffusion Method," Acta Biologiae et Medicine Experimentalis, Vol. 15, 1990, pp. 113-135.

[23] J. M. Vincent, "Distortion of Fungal Hyphae in the Presence of Certain Inhibitors," Nature, Vol. 156, 1947, pp. 850. doi:10.1038/159850b0

[24] J. Mendham, R. C. Denney, J. D. Barnes and M. J. K. Thomas, "Vogel's Text Book of Quantitative Chemical Analysis," 6th Edition, Prentice Hall, Upper Saddle River, 2000 . 